\title{
Quail husbandry and welfare systems at Songhai-Delta farm: Profitability of enterprise
}

${ }^{1}$ Odafe Shalome, G. and ${ }^{2}$ Nojuvwevwo, L. I. ${ }^{I}$ Bio-resources and Food Process Technology Laboratory,

${ }^{2}$ Department of Animal Science, University of Benin, Benin-City, Nigeria

Corresponding author: gideon.odafe-shalome@uniben.edu;

Abstract $+234(0) 8181303319$

Quails are small sized pheasants having a long history of domestication and utilization. The management and welfare systems of Quail production at Songhai Delta farm were surveyed and reviewed. The young quails were sexed by the feather and vent methods when at 6 weeks old and they begin to lay eggs at about that age. Fertile eggs are managed in hatchery until chicks are hatched. Other set of eggs laid are also collected and sold in the farm shop. The quails were fed three types of ration - starter mash at 1-4 weeks of age, grower mash 4-6 weeks and layer mash as from 6 weeks of age. Quails are susceptible to some common poultry diseases; but good management and welfare practices ensure safety and healthy birds. A ratio of Imale to 3 females is the stocking rate in breeder cages in the farm, to obtain fertile eggs. High feed cost and poor market for farm products were the most significant problems of the enterprise. The cost and return estimate for quail bird production indicate that quail venture is highly profitable. The bird has early sexual maturity resulting in a short generation intervals and high rate of lay. Thus, raising quail offers many advantages when compared to producing other domestic or food animals. Quail venture is excellent and recommended for beginners in poultry business, because the birds begin to lay eggs at young age of about 6weeks; and can be slaughtered for food at 5weeks of age. Many developing countries presently faced with problem of inadequate supply of animal protein should find quail production a viable industry. The study recommends a step up of extension services to enlighten farmers and the populace on the importance of quail meat and eggs and the profitability of quail farming.

Keywords: Songhai farms, Quail husbandry, meat and egg marketing, profitability.

\section{Les Systèmes d'élevage et de bien-être des cailles à la ferme Songhai-delta - Rentabilité de l'entreprise}

\section{Résumé}

Les cailles sont de petite taille ayant une longue histoire de domestication et d'utilisation. Les systèmes de gestion et de bien-être de la production de cailles à la ferme du delta de Songhai ont été considéré et examinés. Les jeunes cailles sont sexées par les méthodes de 'feather and vent' lorsqu'elles ont 6 semaines et qu'elles commencent à pondre des oufs vers cet âge. Les œufs fertiles sont gérés dans l'écloserie jusqu'à ce que les poussins soient éclos. D'autres œufs pondus sont également recueillis et vendus dans la boutique de la ferme. Les cailles ont été nourries de trois types de ration - purée de démarrage à l'âge de 1-4 semaines, purée de grower 4-6 semaines et purée de couche à partir de 6 semaines d'âge. Les cailles sont sensibles à certaines maladies courantes de la volaille; mais de bonnes pratiques de gestion et de bien-être assurent la sécurité et la santé des oiseaux. Un rapport de 1male à 3 femelles est le taux de stockage dans les cages d'élevage dans la ferme, pour obtenir des oeufs fertiles. Le coût élevé des aliments pour animaux et le mauvais marché des produits agricoles ont été 


\section{Quail husbandry and welfare systems at Songhai-Delta farm}

les problèmes les plus importants de l'entreprise. L'estimation du coût et du rendement de la production d'oiseaux caille indique que l'entreprise de cailles est très rentable. L'oiseau a une maturité sexuelle précoce résultant en un intervalle de génération court et un taux élevé de produire des oeufs. Ainsi, l'élevage de cailles offre de nombreux avantages par rapport à la production d'autres animaux domestiques ou alimentaires. L'entreprise de caille est excellente et recommandée pour les débutants dans le secteur de la volaille, parce que les oiseaux commencent à pondre des oufs à un jeune âge d'environ 6 semaines; et peut être abattu pour la nourriture à l'âge de 5 semaines. De nombreux pays en voie du développement confrontés à un problème d'approvisionnement insuffisant en protéines animales devraient trouver la production de cailles une industrie viable. L'étude recommande une augmentation des services d'extension pour éclairer les agriculteurs et la population sur l'importance de la viande et des aufs de caille et la rentabilité de l'élevage de cailles.

Mots-clés: Fermes Songhai, Élevage de cailles, commercialisation de la viande et des œufs, rentabilité.

\section{Introduction}

Quails are small game birds generally considered to belong to the order Galliformes, and two families: the Phasianidae (old world quail) and the Odontophoridae (new world quail) according to Cox et al. (2007). The quails are migratory birds, believed to have originated from South East Asia, but found across Asia, America and Europe. The birds were introduced into Japan from China in the $11^{\text {th }}$ century; and then most recently into Nigeria from Japan in 1992 (NVRI, 1994). They are used as pets and as food, providing eggs and meat (DAFF, 2013). There are indications that in historic times Quails were the recipe for the manna divinely provided from the sky when the Jews were in the wilderness. Evidently in Nigeria there is a gap between the knowledge of commercial quail production and its benefits whereas commercial poultry business, respecting the domestic fowl and turkey, is thriving and progressing. However, there is a current realization that quails have medicinal and nutritional properties, and quail farming has high economic potential. Although quail farming is an uncommon business in Nigeria the prospects seem promising; it is a viable alternative which offers to encourage and contribute to sustainable development in poultry industry; and at the same time alleviate poverty amongst farmers in Nigeria. Hence, there appears to be an increasing interest in quail farming and an increase in the demand for quail birds and eggs in the country. Therefore, to keep pace with this increasing demand, efforts are being intensified by some stakeholders, such as the Songhai-Delta farms, towards increasing the level of production of quails in the country. The study was conducted by way of survey, participation and review, to provide useful information about quail production as demonstrated at SonghaiDelta farm, which is a model unit and training center. Thus the study assessed the production techniques and determined the profitability of quail bird enterprise as demonstrated at the farms. Specifically, the study attempted to identify the requirements of housing, feeding and healthcare of quails, and how these should be provided for in quail farms. The constraints affecting the management and operations in quail bird production, and the remedial systems for combating these were also identified. In addition, an attempt was made to determine and appraise if there were semblances or differences between Songhai-Delta quail management system and those of quail culture elsewhere, around the world. 


\section{Methodology}

\section{Study Location}

The study was undertaken at the Quail Unit, Songhai Demonstration Farms, located at Amukpe, Sapele, Delta State, situated in the rain forest belt of Nigeria between latitude $5.81^{\circ} \mathrm{N}$ and $6.4^{\circ} \mathrm{N}$ and longitude $5.72^{\circ} \mathrm{E}$ and $6.0^{\circ} \mathrm{E}$. The area lies 11 meter above sea level and is characterized by tropical equatorial climate, with mean daily temperature range of $25.8^{\circ} \mathrm{C}-36.5^{\circ} \mathrm{C}$, annual rainfall $2673.8 \mathrm{~mm}$, and Relative humidity 85 $95 \%$.

\section{Data collection}

Data on management of quail birds include: housing, breeders, hatching, brooders, adult birds, sexing, feeding and watering. Health management and marketing were collected by visual examination and questionnaire administered to technical and management staff in the poultry and quail units. In addition, it was necessary for these researchers to participate in some daily operations in the quail unit to enable clear observations and obtain primary information on various aspects of quail management. This included cost of various purchases and sales related to quail enterprise in the farms.

The design and dimensions of quail housing unit was examined and the cost was determined. The height of the dwarf wall, type of roofing sheet, floor type, lightening and bedding materials were noted. The sizes of the cages (length, height and width) were measured. The stocking rate and stocking density were evaluated. The extent of furnishing feeders, drinkers and accessories were also taken into consideration.

\section{Source of quail birds and welfare systems}

The birds were brought in from station, Songhai-Cotonou demonstration farm, Benin Republic. Breeder hens were managed until they produced eggs. Fertile eggs were incubated until when hatched. Chicks were brooded into growers which were reared to maturity; and then sold to marketers and consumers. At every stage measurements and welfare requirements including spacing, lighting, temperature, health care and type of feed for brooders, growers and adult birds were recorded for analysis.

\section{Model specification and determination of profitability}

The cost of birds, cost of feed, cost of labor, selling price of egg, selling price of an adult quail and fixed cost incurred during the husbandry period were determined and recorded. Then the cost and return in quail bird production was calculated using Gross Margin analysis. Gross margin is the money available to cover the operating expenses and still leaves a profit (Downey and Trocke, 1981) and profitability on the other hand is state of yielding a financial profit or gain (Business Dictionary, 2013). Thus Gross margin and Net Income were computed and specified as follows:

$$
\begin{gathered}
\mathrm{GM}=\mathrm{TR}-\mathrm{TVC} . \\
\mathrm{N} \text { I }=\mathrm{GM}-\mathrm{TFC} .
\end{gathered}
$$

Where: $\mathrm{TR}=$ Total Revenue; $\mathrm{TVC}=$ Total Variable Costs; GM = Gross Margin

$$
\mathrm{NI}=\text { Net Income; } \mathrm{TFC}=\text { Total Fixed }
$$
Cost.

\section{Results and discussion \\ Characteristics of quails at Songhai-delta farm}

Two main kinds of quails were reared at Songhai-Delta. These are the Japanese quail (Coturnix japonica) and the American quail (Coturnix coturnix). The two kinds belong to the pheasant family (Phaesianidae) of migratory birds, and are considered suitable for breeding (Cox et al., 2007). Breeder birds were reared in the farm; and birds began to lay eggs at 6weeks of age. Fertile eggs were managed in hatchery until chicks were hatched. The newly hatched quail chick weighed averagely 6 - 8 grams (Table1) which corroborated report by Hall (2012). The chick grew rapidly during the 


\section{Quail husbandry and welfare systems at Songhai-Delta farm}

first few days and became fully feathered at about 3 weeks of age; and then attained full maturity at 6weeks, thus corroborating previous observation (Hall, 2012). The young quails [Coturnix spp] reared at Songhai delta farm had biege-yellow plumage, with stripes and patches of brown. They showed a semblance in appearance, to turkey poults which are also reared at the farm; but which are significantly bigger in size. This study recorded live weights (Table 1) which fell within the range of values previously reported (Hall, 2012). The young males began to crow at 5 - 6 weeks old when they attained maturity (Table 1). The average weight of an adult male quail ranged between 100-130 grams corresponding to previous report (Mizutani,
2003). Male birds could be identified readily by the rusty dark brown color of the breast feather. Morphologically, males do have a cloacal gland, a bulbous structure located at the upper edge of the vent which secretes a white foamy substance. That substance was examined as indicator in assessing the reproductive fitness of the male, as recommended (Ortlieb, 2013). Adult female quail are slightly heavier than the male weighing from 120 - 160 grams; similar to the reports by Ortlieb (2013). Female bird showed similar plumage color with the male except that the feathers on female throat and upper breast were long, pointed and much lighter. Also the light tan breast feathers were characteristically black-stripped.

Table 1: Characteristics of Songhai quails and management practices

\begin{tabular}{ll}
\hline Indices & Observation \\
\hline Quail species & $\begin{array}{l}\text { Cortunix japonica, Cortunix } \\
\text { cortunix }\end{array}$ \\
Weight of chick & $6-8 \mathrm{~g}$ \\
Color of chick & Yellow with brown specks \\
Weight of adult male & $100-130 \mathrm{~g}$ \\
Weight adult female & $120-150 \mathrm{~g}$ \\
Color & Rusty brown with black stripe \\
Age at sexing & 6weeks \\
Sexing method & Feather and vent \\
Sex ratio & $1: 3$ \\
\hline
\end{tabular}

\section{Quail sexing at Songhai-delta}

At Songhai delta farms, young quails were sexed when at 3-6 weeks old. Two recommended methods of sexing quails [the feather method and the vent method] are practiced at the demonstration farm. In the feather method the color of the feather on quail breast was examined when birds were 3 weeks of age; female quails have light colored breast with brown spot while the males have a dark colored breast which show little or no spot. The vent method is performed at 6 weeks of age. The bird was placed on table with its side to examine the cloaca. The cloaca was properly pressed down to see if a bulge would appear, indicating it's a male. Absence of bulge indicated that the bird is female. The vent method tends to be more accurate; hence it is the preferable method used in the farm.

\section{Quail breeding and hatching management at Songhai delta}

Males and females are usually housed in cage together in order to produce fertile eggs. To ensure that newly laid eggs get fertilized within 24hours, researchers recommended sex ratio of 1male: 3 females (Chelmonska et al., 2008); ratio1:2 (Raklin et al., 1998) or ratio1:1 in a small cage (Hall, 2012). At Songhai delta farms the 1:3 sex 


\section{Odafe Shalome and Nojuvwevwo}

ratio is practiced. Following suggestions by Woodward et al. (1973) the males were removed from the cages after 48hours of enclosing with the females; and fertility continued among the females, for up to 2 weeks. The fertilized eggs would roll down the front of the cage and were removed and transferred to storage room [preincubation]. In line with research recommendations, it was necessary to provide light in the pen nearly all day, particularly at night, in order for the breeders to be highly productive at laying (Marsh, 1971; Woodward, 1973; Hall, 2012).

\section{Care of fertile eggs \\ Pre-Incubation}

Observations at the farms indicate that quail hens in cages do not sit on their eggs to warm and hatch them naturally, like the indigenous domestic fowl hens do. Hence at the demonstration farm, fertilized eggs are usually removed from the cages and first kept in cool temperature storage for about 7 days. The eggs are fragile and delicate; hence to avoid shell breakage, tender care needs to be taken during collection and storage. Eggs were collected from cages several times in a day and transferred to the store, air conditioned room, where temperature is maintained within optimum cool range, throughout the period. This practice follows the observations and reports that storage temperature is critical and important for the development of fertilized eggs during room storage (Marsh, 1971; Woodward et al., 1973). It is recommended that room temperature should not be below (cold/frozen) or above (warm/hot) an optimum (cool) range (10$15^{\circ} \mathrm{C}$ ). Outside the optimum temperature range, the fertilized eggs could get dehydrated, damaged or improperly developed during the pre-incubation stage
(Woodward et al., 1973). The eggs are removed from storage room after about 7 days; and then transferred into the incubator as recommended (Marsh, 1971; Woodward etal., 1973).

\section{Incubation}

Quail eggs generally have conical shape and uniform size. The eggs were examined and were cleaned by mild abrasion, to remove specks of droppings and debris on shell; and then eggs were arranged in the incubator, placing the small end down. As with pre-incubation [room storage] incubation temperature is very critical. Late hatching of chicks would result when temperature is too low/cold. On the other hand, too early and irregular hatching may occur if the temperature was too high/hot. Marsh (1971) recommended $37.6^{\circ} \mathrm{C}$ $\left(99.75^{\circ} \mathrm{F}\right)$ as ideal temperature for incubating while Woodward et al. (1973) gave temperature and humidity schedule for a forced air incubator (Table 2). There are different models of incubators including household and commercial types; operating on the principles of forced air incubation or of still air incubation. In Nigeria, household incubators are common and vary in style and in evenness of temperature. At Songhai delta farm still air incubators are used; and the results were satisfactory because incubation temperature was maintained at $37^{\circ} \mathrm{C}$ in accordance with recommendation (Marsh, 1971; Woodward et al., 1973). Eggs are always placed in the incubator with small end down; but it is also very important to turn the eggs regularly during incubation in order to prevent irregular hatching. The eggs were rolled or turned up to $180^{\circ}$ several times daily; until the 14 th day when chicks were near to hatch; according to reports; and as we observed in this study the eggs hatched in 16/17 days. 
Quail husbandry and welfare systems at Songhai-Delta farm

Table 2. Temperature and humidity schedule described for a forced air incubator

\begin{tabular}{lcccc}
\hline Days & \multicolumn{2}{l}{ Temperature } & $\begin{array}{l}\text { Humidity(Wet temperature) } \\
\text { bulb }\end{array}$ \\
& & & & \\
\hline $0-12$ & $99.5^{\circ} \mathrm{F}$ & $37.5^{\circ} \mathrm{C}$ & $87 \mathrm{~F}$ & $30.8 \mathrm{C}$ \\
$13-15$ & $99.0^{\circ} \mathrm{F}$ & $37.2^{\circ} \mathrm{C}$ & $85^{\circ} \mathrm{F}$ & $29.9^{\circ} \mathrm{C}$ \\
$16(10$ hours only) & $98.5^{\circ} \mathrm{F}$ & $37.0^{\circ} \mathrm{C}$ & $82^{\circ} \mathrm{F}$ & $27.8^{\circ} \mathrm{C}$ \\
$16-17$ & $99.5^{\circ} \mathrm{F}$ & $37.6^{\circ} \mathrm{C}$ & $90^{\circ} \mathrm{F}$ & $32.3^{\circ} \mathrm{C}$ \\
\hline
\end{tabular}

Source- Woodward et al. (1973)

\section{Hatching}

At Songhai farms the hatching procedure described by Ortlieb (2013) were followed. Before chicks were hatched, the floor of the incubator was covered with a material with rough surface; a flat piece of wire mesh bearing $0.5 \mathrm{~cm}$ holes was used. This surface permitted the newly hatched birds to get their feet under them and to keep the bird upright without falling over fragile legs. Observations revealed that some newly hatched chicks fell and flatten themselves over their fragile legs on a smooth incubator floor causing dislocation thereby never able to stand on their feet. Such observation had previously been recorded elsewhere (Ortlieb, 2013) and was confirmed in this study. Once hatched chicks remained in the incubator until they got dried and fluffed out in about 24 hours. Thereafter the chicks were removed from incubator; and for the purpose of this study the chicks were weighed and then placed in a brooder. The average weight of the hatched Coturnix chicks recorded in the farm was $7 \mathrm{gm}$ which fell within reported range (Ortlieb, 2013).

\section{Quail brooding management Songhai} delta

\section{Brooder Box}

Clean cardboard [poly cellulose fiber] boxes free from contaminants were used for brooding. According to recommendations the box was well covered; small holes [vents] were cut on one end of the box. A 60 watts light bulb was suspended from the top of the box, to about and 8-10 $\mathrm{cm}$ above the floor, toward one end of the box (Ortlieb, 2013). The light bulb provided constant lighting and constant heating; while the small holes [vents] allowed for ventilation and distribution of heat throughout the interior of brooder box; and hence temperature could be maintained. Brooder floor was covered with newsprint material that could absorb moisture and droppings. Wire screen was also laid on as a roughened surface to hold the chicks firmly. Small trays were placed on floor of box for feed and water; and the chicks are fed twice daily. Chicks were reared in the box-type brooder for 3-4 weeks during which period the chicks developed into growers. Thereafter they were transferred from brooder box to brooder cage.

\section{Brooder cage}

The growers' welfare and care were essentially the same as for the adult birds. Following recommendations, extra light was provided in the brooder cage system for 2-4 weeks, until birds were sexed. The growers were sexed at 6 weeks of age when they attained adulthood; as described and previously described (Hall, 2012; Ortlieb, 2013).

\section{Feeding chicks and growers}

The feed recommended for the quail chicks should be a finely ground, high protein $(28-30 \%$ CP) starter feed (Shim, 2005). However, at Songhai delta farms commercial chick-starter was used. Feed was placed in shallow aluminum trays. To avoid overcrowding of the chicks around 


\section{Odafe Shalome and Nojuvwevwo}

feed trays and possible accidents and deaths, that could result, the trays were well spaced out on the floor of the pen, as appropriately recommended (Oluwatomi, 2010; Hemid et al., 2010; Hall, 2012; Ortlieb, 2013). The number of feed trays depended on the size of the boxes and on the number of birds.

\section{Adult quail management at Songhai- delta}

\section{Housing of quail}

Adult birds are those of 6 weeks age and above; and they are reared in quail house. In accordance with recommendations, the quail house was made up of dwarf wall, at least one meter in height, constructed with cement blocks and aluminum sheet as roof. The dwarf wall was necessary to provide adequate lighting and cross ventilation, while the aluminum roofing sheet prevented the effect of direct sunlight, wind and rain, while providing warmth within the quail house. The floor of the house was made of concrete, properly cemented, to enable easy cleaning and washing. Wood shavings were spread evenly on the floor. In accordance with Coutts and Wilson (1990) and Mizutani (2003) a foot dip with disinfectant was located at the entrance of the house to prevent the invasion of disease causing agent.

\section{Cages}

At Songhai delta farms provision is made for 50 cages in the quail house. The cages were built according to specification, $0.5 \mathrm{~m}$ high and $2 \mathrm{~m}$ long (Chelmonska et al., 2008). According to this researchers, for breeding purposes the recommended stocking density for a one square meter cage [2x1x0.5m] was 32 quail birds ( 8 males + 24 females), while for the purpose of egg production 40 female birds were placed together in the cage. To reduce pecking in the cages the tips of the beaks of the males were cut off using wire-cutting pliers according to earlier documentation (Hemid et al., 2010; Igado and Aina, 2010;
Oluwatomi, 2010). Cleaning was done daily in the quail house. The cages were cleaned with metal sponge. It was possible for the farm to provide a piece of sheet metal fabricated according to specification (10.2 $\mathrm{x} 40.6 \mathrm{~cm} / 4 \mathrm{x} 16 ")$. The narrow edge of this was bent down to an angle of $90^{\circ}(0.6 \mathrm{~cm} /$ $\left.0.25^{\prime \prime}\right)$ from the edge. This formed a blunt instrument that could be placed in the space between hardware cloth floor and sheet metal subfloor, and enabled the cleaner to push the droppings of the birds off the metal to the rear of the cage. Cardboard was placed below the metal floors to trap the droppings and hold them until recovered and discarded.

\section{Light requirements}

Research indicated that quails require 14-18 hours of light per day to maintain maximum egg production and fertility (Coutts and Wilson, 1990). Hence proper lighting was provided in the quail house throughout the day and particularly at night. However male and female birds that were not used for breeding, but were reared only for meat were exposed to 18 hours of low-intensity light per day. The reason for that was to prevent sexual behavior. High intensity light could initiate sexual maturity; and could make them more excitable and expend energy in fighting and mating. On the other hand, low intensity light promoted docility and cause this set of birds to fatten more quickly (Coutts and Wilson, 1990; Mizutani, 2003; Hemid et al., 2010; Igado and Aina, 2010; Oluwatomi, 2010).

\section{Quail feeding and nutrition}

Shim (2005) reported that quails can utilize diets containing 2200 to $3400 \mathrm{kcal} / \mathrm{kg}$ metabolizable energy (ME) equally well if the protein level is between $20-25 \%$. Hence they recommended a level of $23 \%$ dietary protein for optimal growth of growers; and dietary protein level of $20 \%$ for layers to achieve optimal production, fertility, and hatchability of eggs. Shim (2005) also recommended that if commercial quail feed 


\section{Quail husbandry and welfare systems at Songhai-Delta farm}

is not available, commercial chick starter, for domestic fowl can be used. Alternatively, a homemade mix of soybean and com meal (1:1 ratio) would be feasible. At Songhai delta farms adult quails were fed between $14 \mathrm{~g}$ and $18 \mathrm{~g}$ of feed per day. The quail birds were fed two types of ration; starter mash was fed to the chicks at $0-4$ weeks of age; layer mash was fed to growers at 4 - 6 weeks of age; and same layer mash was fed to adults as from 6 weeks. The two types of feed were given during the production period (a starter mash and a layer mash). The adult birds were administered the layer mash (24-26\% CP) and water twice daily. Feed contained high source of calcium such as crushed eggshells, coral sand for sustained egg production. The feeds were also mixed with leaves of moringa and pawpaw to add to bulkiness and serve as a source of vitamins precursor.

\section{Provision of water}

Water was provided ad lib for the chicks, growers and adults. The water containers used were plastic bowls modified and cut into shape of troughs, which enabled the small birds drink easily from the trough. As recommended the troughs were held firmly in position in the brooders and cages, by placing clean pebbles to add weight and keep trough from turning over or spilling water. The pebbles also prevented the birds from drowning in accordance with suggestions (Oluwatomi, 2010; Ortlieb, 2013).

\section{Health care of quails at Songhai delta}

According to reports quails are susceptible to some of the common poultry diseases; including viral infections such as avian encephalomyelitis, fowl pox, infectious bronchitis and Newcastle disease (Hill and Raymond, 1962, Edgar et al., 1964). They are also susceptible to bacterial pathogens; Salmonella pullorum, S. gallinarum, $S$. typhimurium, Pasteurella multocida, and Escherichia coli. Fungal infections include
Aspergillus fumigates (Mdegela et al., 2002; Magothe et al., 2012). In addition, leukosis and fowl paralysis were reportedly observed in quails (Wight, 1963; Bigland et al., 1965). Parenteral administration of terramycin through water is the prescribed treatment for most poultry diseases (Magothe et al., 2012). However, terramycin residue in eggs laid within two weeks following treatment have also been reported (Magothe et al., 2012).

At Songhai farms, birds were healthy during the period of study. They were not vaccinated against any poultry diseases. However, the birds were routinely dewormed against endoparasites. Antibiotics and multi vitamins were administered through feed as necessary. To maintain health of birds daily cleaning of quail house and cages was practiced; and droppings were removed twice a week.

As part of health management of the birds it was necessary to maintain Stocking density for the different classes; extra males from brooder cage not required for breeding were sold to consumers for meat. Breeder males and all the females were stocked in cages at rate of 1:3 as previously mentioned (Coutts and Wilson, 1990; Mizutani, 2003; Hemid et al., 2010; Igado and Aina, 2010; Oluwatomi, 2010).

Cost and return analysis of quail bird production

The cost and return estimate for quail bird production are reflected in Table 3. The result indicated that the cost of production of 100 quail birds was N33,500. 00 which included the cost of day old chicks, cost of feed, cost of labor, cost of chick vaccination and drugs, cost of feeders and drinkers. The cost of transportation and permanent structures, housing, bore hole and other infrastructure were not included. However, the cost of the cages was considered. The total revenue realized from the sales was N50,000.00. The gross margin was N20,500.00 while the net farm income was 


\section{Odafe Shalome and Nojuvwevwo}

$\mathrm{N} 14,500.00$. The gross margin is the difference between total return and total variable cost. Total return (revenue) included sales from birds, eggs and litters.
The variable cost is the cost of birds, feeds, and wages on labor and veterinary services. The total fixed cost sums the cost of cages and the cost of feeders and drinkers.

Table 3: Gross margin analysis of producing 100 quail birds for meat

\begin{tabular}{llll}
\hline Cost & Quantity & $\begin{array}{l}\text { Unit Price } \\
(\mathbf{N}: \mathbf{K})\end{array}$ & Total Price (N:K) \\
\hline Revenue & 100 & 500 & 50000 \\
Day old & 100 & 100 & 10000 \\
Feed Starter (1-3wks) & $52.5 \mathrm{~kg}$ & 5250 & 5250 \\
Feed Layer (46wks) & $52.5 \mathrm{~kg}$ & 5250 & 5250 \\
Labor cost & 1 & $200 /$ man day & 9000 \\
Total variable cost & & 29500 \\
(TVC) & & \\
Gross margin(TR-TVC) & & 20500 \\
Total fixed cost (TFC) & & 6000 \\
Total cost (TVC+TFC) & & 35500 \\
Net income (GM-TFC) & & & 14500 \\
\hline
\end{tabular}

NB: Breakdown of Total Fixed Cost (Housing 4000 naira, 4 Drinkers 1000 naira, 4 Feeding Troughs 1000 naira, 2 Dozen of Crate 500 / Dozen)

Cost and return analysis of quail egg production

In Table 4, the Gross margin for quail egg production is shown. The revenue realized from the sales of 600 crates of quail eggs was N480,000.00 with an average of 75 eggs per day while the total cost of production was N181,250.00, the gross margin was $\mathrm{N} 305,750.00$ while the net income was $\mathrm{N} 298,750.00$. The rate of mortality was not included in the data analysis.

Table 4: Gross margin for quail egg production

\begin{tabular}{llll}
\hline Item & Quantity & Unit Price $(\mathrm{N})$ & Total price $(\mathrm{N})$ \\
\hline *Revenue & 800 crate & 600 & 480,000 \\
$\begin{array}{l}\text { Variable cost } \\
* \text { Cost of birds }\end{array}$ & 100 & 100 & 10,000 \\
$*$ Cost of feed & & & \\
Starter (1-3 wks) & $52.5 \mathrm{~kg}$ & 5,250 & 5,250 \\
Laying mash & $86.0 \mathrm{~kg}$ & 86,000 & 86,000 \\
$*$ Labor cost & 1 & $200 /$ man day & 73,000 \\
$*$ Total variable cost & & 174,250 & \\
$*$ Gross margin(TR-TVC) & & 305,750 & \\
$*$ Total fixed cost & & 7000 & \\
$*$ Total cost(TFC+TVC) & & 181,250 & \\
Income & & 298,750 & \\
\hline
\end{tabular}

NB: Breakdown of Total Fixed CosH(ousing 4000 naira, 4 Drinkers 1000 nair,at FeedingTroughs 1000 naira 2 Dozen of Crate 500 / Dozen)

Constraints of quail farming in the delta study area

The constraint to quail production observed were those common to poultry business.
Emeyonu and Okafor (2003) had indicated that those common constraints included stock procurement, pest and diseases control, inadequate veterinary services, 


\section{Quail husbandry and welfare systems at Songhai-Delta farm}

high cost of feed, and poor market among others. In this study, poor market was the most significant major problem. In addition, to that was the high cost of feed, which is typical of the Nigerian poultry. Also there were constraints associated with animal behavior and animal welfare. For example, the shrill crowing of the males was disturbing; when males and females were kept together fighting and pecking for dominance between the males was rife. Some males got blind or even got killed as a result confirming the observation previously reported. This perhaps was the reason why Hall (2012) recommended that the optimum method for obtaining fertile eggs is to enclose one male and one female in a small cage; and this would eliminate the social vice among the male birds. Due to tenderness and very small size of the chick fatalities associated with environmental stress did occur; the spacing, heating and fighting were the most critical factors of environment; and these required constant checking in quail husbandry. Quails tend to age more rapidly than other domestic fowl and laying birds; thereafter replacing birds or restocking the unit each year is necessary to remain in business (Marsh et al., 1982). Unlike domestic fowl extra efforts to protect and secure the quail birds are needed; mature birds are restless, once they escape from cages they are difficult to recapture. Like other poultry species quails are susceptible to some pests, parasites, and diseases; but unlike domestic fowl quail cages require cleaning on daily basis to eliminate strong odor that is produced and the possible effects (Emeyonu and Okafor, 2003).

Prospects and profitability of quail venture Raising quails offer many advantages when compared to producing other poultry or livestock. The quail bird has early sexual maturity resulting in a short generation interval, high rate of lay and much lower feed and space requirements than the domestic fowl (Podems et al., 1975; Hemid et al., 2010). Quail birds are small body birds which require little space. A cage permitting each bird $225 \mathrm{~cm}^{2}$ of floor space (44 birds $/ \mathrm{m}^{2}$ ) is the minimum requirement. The cage need not be more than $15 \mathrm{~cm}$ in height. The stocking density is approximately 32 quail birds to one square meter ( 8 males, 24 females) is appropriate to avoid overcrowding. The natural feeds for quails are grains and seeds. However, quails birds grow faster when they consume poultry feeds. The quails are efficient converters of feed. With each egg deposited by a female quail is equivalent to of 8 percent of her own body weight, compared to 3 percent in the case of chickens (Chelmonska et al., 2008). The returns to raising quail for commercial purposes are high and the turnover is quick. Female quails mature in about six weeks and start laying eggs at 50 days old. Hence, the bird continues to produce eggs at economic levels for at least a year (Hemid et al., 2010). Oluwatomi (2010) opined that given proper care, a quail hen has the capacity to lay 24 eggs in one month, about 200 eggs in the first year of lay, and then 288 eggs in subsequent years. The life expectancy of quails is between $2-3$ years, implying that that the birds are productive, yielding returns to investments throughout their lifecycle (Oluwatomi, 2011). The performance of Japanese quails at SonghaiDelta farms examined in this study seemed to confirm those reports. Quails have been reported to be affected by common poultry diseases, but are fairly resistant. We however observed no incidence of disease, evidently because of good and efficient management practices in the farm. Japanese quails are hardy birds, thrived on concrete floor and in small cages, and were inexpensive to keep. Thus, the prospects of quail farming are high. Among the economic advantages are the creation of small-medium scale business and 


\section{Odafe Shalome and Nojuvwevwo}

employment for many citizens; the quick maturity of birds in about two months; high sales turnover; and additional source of income to the households. There is also the advantage to increase animal protein supply; to provide lean meat and enhance the nutritional status and health of families and communities.

\section{Summary and recommendation}

This study reviewed the welfare of quail breeder birds, care of fertile eggs, incubation and hatching, brooding and rearing of chicks, and adult management in the Songhai Delta farm. The model techniques in housing, breeding, brooding, sexing, feeding, health care, and the challenges in production were examined and highlighted. Data on marketing of egg and adult birds were collected and examined using descriptive statistics and gross margin analysis. Findings indicate that quail production techniques at Songhai Delta, correspond with recommended methods. The venture is profitable, while the main challenge was inadequate sales outlet for mature birds and eggs, due to inadequate publicity; although awareness of the nutritional value of the quail is on the rise, there is still very low level of interest in quail farming as a promising enterprise. This study recommends a step up of extension services to farmers and marketers of poultry products, to enlighten the populace on the importance of quail meat and eggs and the profitability of quail farming.

\section{References}

Akpan, I. A. and Nsa, E. E., 2009. Growth performance of growing Japanese quail Coturnix coturnix japonica, fed diets containing different crude protein levels. Proc. 14th Ann. conf. Anim Sci Assoc of Nigeria (ASAN).14th-17th Sept. LAUTECH, Ogbomoso, Nigeria, pp553-555.

Bigland, C. H., DaMassa, A. J., and Woodard, A. E., 1965. A flock survey of diseases of Japanese quail (Coturnix coturnix japonica), and experimental transmission of selected avian pathogens. Avian Diseases 9:212-219.

Chelmonske, B., Jerysz, A., Lukaszewicz, E., Kowalczyk, A. and Malecki, I. 2008. Semen Collection from Japanese Quail (Coturnix japonica) using a teaser Female. Turkey Journal Veterinary Animal Science 2008; 32(1): 19-24.

Coutts, J. A. and Wilson, G. C. 1990. Egg Quality Handbook, Queensland Department of Primary Industries, Australia.

Cox, W. A., Kimball, R. T., and Braun, E. L. 2007. Phylogenetic position of the new World Quail (Odontophoridae): Eight nuclear Loci and three Mitochondrial Regions contradict morphology and the ibleyahlquisttapestry. The Aukl24 (l):71-84, 2007

DAFF, 2013. Structure and dynamics of the quail. Common wealth of Australia.1-5,

Downey, S. W. D., and Trocke J. K. 1981. Agribusiness Management. New York: Me Graw-Hill book company, USA, 1, 4-7, 39

Edgar S. A., Waggoner R. and Flanagan C. 1964. Susceptibility of coturnix Quail to certain disease producing agents common to poultry. Poultry Science.43:1315.

FAO, 1990. Food and Agricultural magazine vol 2 No.4 Food and Agricultural Organisation ESN Nutrition profile Nigeria, Rome, Italy.

FAO, 2004. Small scale poultry production.Food and Agriculture Organization.Animal Production 


\section{Quail husbandry and welfare systems at Songhai-Delta farm}

and Health.Village Poultry Consultant. Waimana New Zealand pp. 1-5.

FDLPCS, 1992. Nigeria livestock information Service pers. Communication.: Federal Department of Livestock and Pest Control Services. National Livestock Vol 1.National Synthesis. Resource Inventory and Management Ltd. Jerso), JE4 8UD, UK

Hall, G. 2012. Brown Quail and its Management. 2012-05, Brown quail and its management.pdf.

Hemid A.F.A., Abd El-Gawad A.K., ElWardany I., El-Daly, I.F., and AbdEl-Azeem, N. A. 2010. Alleviating Effects of some Environmental stress factors on productive performance in Japanese quail 2. Laying performance World Journal of Agric. Sciences 6(5), 517-524.

Igado, O. O., and Aina, O. O. 2010. Some Aspects of the Neurometrics and Oculometrics of the Japanese Quail (Coturnix coturnix japonica) in Nigeria. Journal of Morphological Science, 27(3-4): 133-135.

Ikheloa, E. E., and Iredia, G. 2005. Analysis of survival rates of chick in poultry farm in Edo state. Proceedings of 39th Annual Conference of ASAN, Benin-City, Edo state, Nigeria.

Marsh, A. F. 1971. Quail Manual, 7th edition. Marsh Farms, Garden Grove, California.52 pp.

Magothe, T. M., Okeno, T. O., Muhuyi, W. B., and Kahi, A. K. 2012. Indigenous chicken production in Kenya: Current status. World's Poultry Science Journal. 68: 119132.

Mdegela, R. H., Yongolo, M. G., Minga, U. M., and Olsen, J. E. 2000.
Molecular epidemiology of Salmonella gallinarum in chickens in Tanzania. Avian Pathology, 29(5) $457-463$.

Mizutani, M. 2003. The Japanese Quail. Laboratory Animal Research Station. Nippon Institute for Biological Science, Kobuchizawa, Yamanashi. J a p a n . (http://www.angrin.tlri.Rov.tw/ape c2Q03/Chapter5JPQuail.pdf): Retrieve Dec15,2009.

Mizutani, M. 2003. The Japanese Quail. www.angrin.tlri.gov.tw/apec2003/ chapter /pdf.NVRI, (1994). Farmer training on quail production and health management. National Veterinary Research Institute Vom, Nigeria. P.44.

Msoffe, P. E. M., Mtambc, M. V. A., Minga, U. M., Gwakisa, P. S., Mdegela, R. H. and Olsen, J. E. 2002. Productivity and natural disease resistance potential of free ranging local chicken ecotypes in Tanzania. Livestock Research for rural devt, 14(3), 2002.

Okafor, R. M., Odii, M. A., Emeyonu, C. A., Obih, U. 2006. Profitability analysis of poultry production in Imo state, Nigeria. In Adepoju S.O.

Okeno, T. O., Kahi, A. K., and Peters, J. K. 2012. Characterization of Indigenous Chicken Production Systems in Kenya. Tropical Animal Health and Production. 44:601608.

Oluwatomi, O. 2010. Raising Quails: www.tnbune.com.ng/index.phpAve alth

Ortlieb, G. 2013. Raising Coturnix Quail.www.howtoraisequaH.com/ coturnix quail.

Podems, M. 1975. Coturnix Quail Challenges the Chicken. Organic Gardening and Farming, June: 36- 
41.

Psifidi, A. G., Banos, O., Matika, D., Tadelle, R., Christley, P., Wigley, J., Bettridge, 0., Hanotte, T., Desta, P., Kaiser K. 2014. Identification of SNP Markers for Resistance to Salmonella and IBDV in Indigenous Ethiopian Chickens.Proc. 10th World Congress of Genetics Applied to Livestock Production. Ethiopia.

Randall, M., and Bolla, G. 2008. Raising Japanese Quail. State of New South Wales, Department of Primary Industies. Prime Fact 602, 2nd Edition.

Rankling, F. W., Artin, A., Lison G. M., Artin, D. and Nnabelle, M. A. 1998. Quail: An egg and meat production system.

Safalaoh, C. L. 2001. Village Chicken upgrading Programme in Malawi, World Poultry Science Journal, 57: 180-187.

Sahin, N., Akdemir, F., Orhan, C., Kucuk, 0., Hayirli, A., and Sarvn, K. 2008. Lycopene-enriched Quail egg as functional food for humans. Food Res Int. 41: 295-300.

Sainsbury, D. 1992. Poultry health and management: chicken, ducks, turkey, geese, quail $3^{\text {Rd }}$ edition.
Shanaway, M. M. 1994. Quail Production System: A Review, Animal production and health division, Food and Agriculture Organization of The United Nations. Rome.

Shim, K. F. 2005. Nutrition and Management of Japanese Quails in the Tropics. www.that quail place.com.

Sonaiya, E.B., and Swan, S.E.J. 2004. Small-scale poultry production technical guide. FAO, United Nations, Animal production and health manual. FAO, Rome.

Tunsaringkarn, T., Tungjaroenchai, V., and Siriwong, W. 2013. Nutrient benefits of Quail (Coturnix coturnix japonica) eggs. Int. Journ of Sci and Research publictn.3 (5). May 2013

Wight, P. A. L. 1963. Lymphoid leucosis and fowl paralysis in the quail. Veterinary Record 75(27):685-687.

Woodward, A. E., Abplanalp, H., Wilson, W. O. and Vohra, P. 1973. Japanese Quail Husbandry in the Laboratory, Dept. of Avian Sciences, University of California, Davis. 22 pp.

Received: $7^{\text {th }}$ February, 2021 Accepted: $15^{\text {th }}$ August, 2021 